\title{
Polymorphism at position T-129C in the promoter region of $A B C B 1$ gene in peptic ulcer patients: a case control study
}

\section{Marta Żebrowska-Nawrocka}

Uniwersytet Medyczny w Lodzi

\section{Agnieszka Jeleń}

Uniwersytet Medyczny w Lodzi

Jacek Pietrzak

Uniwersytet Medyczny w Lodzi

Agata Lisowska

District Hospital Łęczyca

Dagmara Szmajda ( $\nabla$ dagmara.szmajda@umed.lodz.pl )

Uniwersytet Medyczny w Lodzi https://orcid.org/0000-0002-9524-6032

\section{Adrian Krygier}

Uniwersytet Medyczny w Lodzi

\section{Marek Mirowski}

Uniwersytet Medyczny w Lodzi

\section{Ewa Balcerczak}

Uniwersytet Medyczny w Lodzi

\section{Research article}

Keywords: ABCB1, P-gp, single-nucleotide polymorphism (SNP), Helicobacter pylori, peptic ulcer

Posted Date: September 5th, 2019

DOI: https://doi.org/10.21203/rs.2.13918/v1

License: (c) (1) This work is licensed under a Creative Commons Attribution 4.0 International License. Read Full License 


\section{Abstract}

Background Peptic ulcer disease is one of the most common diseases worldwide. P-glycoprotein encoded by $A B C B 1$ gene is located on the surface of gastric tract cells. Changes in its protein function, as a consequence of polymorphism like T-129C (rs3213619), may have impact the development of some diseases. The aim of this study was to evaluate the potential role of T-129C of ABCB1 gene in peptic ulcer development. To the best of our knowledge, this is the first this kind of research in peptic ulcer diseases. Methods Patients, having attended gastroduodenoscopy because of dyspepsia symptoms and diagnosed at that time as peptic ulcer patients, were enrolled in the study. In all investigated cases, gastric mucosa specimens were taken from the antrum of the stomach. The control group consisted of healthy blood donors from local blood donation center. Overall DNA from 204 patients with peptic ulcer disease and from 94 healthy individuals was tested. The RFLP PCR technique was used for genotype analysis. Results All 204 DNA samples form investigated group and 94 DNA samples form healthy individuals were successfully analyzed. All genotypes for polymorphism in position T-129C of the ABCB1 gene in both groups were in agreement with Hardy-Weinberg equation. Statistical analysis showed no significant differences in frequency of T-129C genotypes between peptic ulcer patients and healthy individuals $(p=0.3977)$. Also, there were no statistically significant differences in the frequency of occurrence of $\mathrm{T}-129 \mathrm{C}$ genotypes between patients infected and uninfected with $\mathrm{H}$. pylori infection $(p=0.1743)$. Conclusion Investigated polymorphism at position $\mathrm{T}-129 \mathrm{C}$ of ABCB1 gene is not associated with $\mathrm{H}$. pylori infection nor with the risk of peptic ulcer disease development.

\section{Introduction}

The increasing number of investigators indicated that genetic factors regulating transport of xenobiotics and inflammation factors production play a major role in the pathogenic process of $H$. pylori infection and, as a consequence, in peptic ulcer disease (PUD) and gastric cancer (GC) development. PUD is a common disease worldwide with a lifetime prevalence in the adult population around $5 \%$ to $10 \%$ over the past decade. Strong association of the disease with a Helicobacter pylori infection is widely recognized, but non-steroidal anti-inflammatory drugs or low-dose aspirin usage are also increasingly important causes of PUD. Eradication of this bacterium improves PUD recovery and is a prophylaxis to reduce the risk of gastric cancer. Antibiotics used in the scheme of eradication therapy are substrates for transporters belonging to $A B C$ family [1-2].

Many polymorphisms of genes responsible in physiology for cell protection are currently being investigated to establish the risk factors of PUD development and also to check their role in the effectiveness of the therapy.

In this work, we conducted an analysis of the T-129C polymorphism of $A B C B 1$ in the group of patients with peptic ulcer disease. $A B C B 1$ (MDR1) encodes a drug transporter protein (P-glycoprotein; P-gp) expressed in many tissues, particularly on the surface of digestive tract cells, blood-brain and bloodtoctic harriore whoro it nlave a nrntontivo ralo. Polymorphisms of that gene could also lead to the Loading [MathJax]/jax/output/CommonHTML/jax.js

Page $2 / 9$ 
reduction of the protective function of P-glycoprotein and, as a consequence, to the promotion of xenobiotic accumulation and/or inflammation $[3,4]$. Especially those in the promoter region of the $A B C B 1$ gene, like single nucleotide polymorphism (SNP) in T-129C position which leads to the exchange of thymine into cytosine in 129 position of the promoter of this gene [5]. On the other hand, many groups of drugs including protein pomp inhibitors (PPIs) are substrates of $\mathrm{P}$ glycoprotein, which is a product of $A B C B 1$ gene. Genetic polymorphisms of this gene alter pharmacokinetics of these substrates and may be associated with the drug resistance in the treatment of various diseases e.g. PUD.

The aim of this study was to determine the potential significance of SNP T-129C of $A B C B 1$ gene (rs3213619) in the development of peptic ulcer in Polish population. According to our state of knowledge, this is the first study of this type among Polish population with a peptic ulcer disease.

\section{Material And Methods}

The presence of polymorphism in the promoter region of the $A B C B 1$ gene in position - 129 was evaluated in 204 unrelated patients (131 women, 73 men). The same cohort was investigated in one of our earlier study [6]. The mean age in the study group was 53 years of age. Patients were enrolled in the study, having attended the Department of Surgery, District Hospital, Łęczyca, Poland, for gastroduodenoscopy because of dyspepsia symptoms and diagnosed at that time as peptic ulcer patients. In all investigated cases, gastric mucosa specimen were taken from the antrum of the stomach. The control group consisted of 94 blood samples collected from healthy blood donors, from the local blood donation center (56 women and 38 men, mean age 33 years of age), geographically and ethnically matched to the patients. Data concerning exposure to carcinogens in patients and controls were not available. Patients who were treated with non-steroidal anti-inflammatory drugs were excluded. The investigation was carried out in accordance with the principles of the Declaration of Helsinki and was approved by the Ethical Committee of the Medical University of Lodz (RNN/195/13/KE). All subjects included in the study gave their informed consent.

\section{Rapid urease test}

To diagnose a Helicobacter pylori infection, a rapid urease test was used (Institute of Food and Nutrition, Poland). H. pylori synthesizes the enzyme urease, which catalyzes the conversion of urea to ammonium ions and carbon dioxide, which leads to a change in the color of the rapid urease test medium from negative (yellow) to positive (red). This infection was detected in half of the examined patients. Based on rapid urease test results, the severity of bacterial colonization was graded as:,+++ and +++. In this study group mild $H$. pylori intensity (+) was observed in 54 , moderate (++) in 26 and severe (+++) in 22 cases.

\section{DNA isolation}

DNA was isolated according to the "Genomic DNA Prep Plus" protocol (A\&A Biotechnology, Poland) from material biopsy specimen of gastric membrane mucosa. The purity and concentration of DNA samples The samples were stored at $-20^{\circ} \mathrm{C}$ until analysis. 
PCR reaction for both the investigated and the control group were performed according to 2xPCR Super Master Mix (Biotool.com, USA) protocol in the volume $20 \mu \mathrm{l} \mathrm{PCR} \mathrm{mixture.} \mathrm{The} \mathrm{PCR} \mathrm{mixture} \mathrm{composed} \mathrm{of} 5$ $\mu \mathrm{l}$ of 2xPCR Super Master Mix, $0.5 \mathrm{mM}$ of each primer (Forward5- CGGC TCTGC T C T TGAG - 3; Reverse 5 T TCACTAC T GCC T TCTAGAG - 3), $50 \mathrm{ng}$ of DNA template and distilled water up to 20 $\mu l$. Negative control (without DNA) was included in every experiment. Conditions of the PCR amplification were as follows: 30 cycles at $94^{\circ} \mathrm{C}(30 \mathrm{~s}), 56^{\circ} \mathrm{C}(30 \mathrm{~s}), 72^{\circ} \mathrm{C}(30 \mathrm{~s})$. PCR products were evaluated during electrophoresis in $2 \%$ agarose gel with ethidium bromide. Products of PCR reaction for SNP T-129C of $A B C B 1$ gene had the size of $258 \mathrm{bp}$.

PCR products were digested by restriction enzyme, specific to the studied polymorphism. The digestion mixture consisted of: $16 \mu \mathrm{l}$ of PCR product, $2 \mu \mathrm{l}$ of 10x buffer C, 0,2 $\mu \mathrm{l}$ of MspA1I (Promega, Poland) enzyme $10 \mathrm{U} / \mu \mathrm{l}$ and $1,8 \mu \mathrm{l}$ of distilled water up to $20 \mu$ l. Digestion by restriction enzyme was performed for SNP T-129C: at $37^{\circ} \mathrm{C}$ for $16 \mathrm{~h}$. Amplified DNA fragments after digestion by restriction enzyme underwent electrophoresis on $2 \%$ agarose with ethidium bromide. Genotypes for the studied polymorphism were identified on the basis of the electrophoresis result (TT - one band $258 \mathrm{bp}, \mathrm{CC}$ - two bands $226 \mathrm{bp}$ and $32 \mathrm{bp}$; CT - three bands $258 \mathrm{bp}, 226 \mathrm{bp}$ and $32 \mathrm{bp}$ ).

\section{Statistical analysis}

STATISTICA 12 statistical software (StatSoft Inc.2012) was used for data analysis. The Chi^2 Pearson test was applied to evaluate conformity between the observed and the expected genotype frequencies in the investigated and control groups according to Hardy-Weinberg equation. Differences in genotype frequencies among peptic ulcer patients and the control group, and the association of various genotypes with other data were determined using the Chi^2 Pearson test and Chi^2 NW test. In each statistical analysis The $p<0.05$ was considered as statistically significant.

\section{Results}

All 204 DNA samples form peptic ulcer patients group and 94 DNA samples form healthy individuals were successfully analyzed. All genotypes for polymorphism in position T-129C of the ABCB1 gene in both investigated group were in agreement with Hardy-Weinberg equation.

Firstly, frequencies of genotypes for studied SNP between peptic ulcer patients and healthy individuals were compared. No statistically significant differences were found $(p=0.3977)$. The prevalence of TT genotype dominated in peptic ulcer patients and in healthy individuals cohort $(97.55 \%$ and $95.74 \%$, respectively). All results are shown in Table 1.

Secondly, the peptic ulcer patients were divided into patients under and equal 55 years old (median age of the group) and patients over 55 years old (median age of the group), and frequencies of SNP T-129C genotypes were compared. However, no statistical significance was found $(p=0.5572)$. 
Table 1. Frequencies of SNP T-129C $A B C B 1$ gene genotypes in peptic ulcer patients and healthy individuals.

\begin{tabular}{|c|c|c|c|}
\hline $\begin{array}{c}A B C B 1 \\
\text { T-129C }\end{array}$ & $\begin{array}{c}\text { Peptic ulcer patients } \\
\text { N=204 }\end{array}$ & Healthy individuals N=94 & \\
\hline TT & $199(97.55 \%)$ & $90(95.74 \%)$ & \multirow{2}{*}{0.3977} \\
\cline { 1 - 3 } CT & $5(2.45 \%)$ & $4(4.26 \%)$ & \\
\hline CC & $0(0.00 \%)$ & $0(0,00 \%)$ & \\
\hline HWE: & 1.000 & 1.000 & \\
\hline
\end{tabular}

After that, peptic ulcer patients were divided according to the results of rapid urease test into two subgroups: patients infected with Helicobacter pylori and patients uninfected with H. pylori. The obtained results are shown in Table 2. CT genotype occurred more frequently in the subgroup of patients uninfected with $\mathrm{H}$. pylori (3.92\%) than in the subgroup of patients with $\mathrm{H}$. pylori infection $(0.98 \%)$. Also here, there was no statistically significant difference $(p=0.1743)$. Further, these subgroups of patients infected and uninfected with bacterium were divided according to gender of patients. In this case of analysis the CT genotype occurred more frequently in the subgroups of: women uninfected and men uninfected with $\mathrm{H}$. pylori than in the subgroups of women and men with infection. It is worth noting that in the case of a subgroup of men with and without $H$. pylori infection, there was a tendency to more frequent occurrence of the $\mathrm{CT}$ genotype in the subgroup of patients not infected with the bacterium in comparison to the subgroup of men infected with H. pylori $(p=0.0894)$.

Table 2. Comparison of T-129C $A B C B 1$ gene genotypes frequencies with $H$. pylori infection 


\begin{tabular}{|c|c|c|c|}
\hline \multirow{2}{*}{$\begin{array}{l}A B C B 1 \\
\mathrm{~T}-129 \mathrm{C}\end{array}$} & \multicolumn{2}{|c|}{ Peptic ulcer patients $\mathrm{N}=204$} & \multirow[b]{2}{*}{$\mathrm{p}$} \\
\hline & $\begin{array}{c}\text { Infected } \\
\mathrm{N}=102\end{array}$ & $\begin{array}{c}\text { Uninfected } \\
\mathrm{N}=102\end{array}$ & \\
\hline TT & 101 (99.02\%) & 98 (96.08\%) & \multirow[t]{3}{*}{0.1743} \\
\hline $\mathrm{CT}$ & $1(0.98 \%)$ & $4(3.92 \%)$ & \\
\hline \multirow[t]{3}{*}{$\mathrm{CC}$} & $0(0.00 \%)$ & $0(0.00 \%)$ & \\
\hline & \multicolumn{2}{|c|}{ Women $\mathrm{N}=131$} & \\
\hline & $\begin{array}{l}\text { Infected } \\
\mathrm{N}=65\end{array}$ & $\begin{array}{c}\text { Uninfected } \\
\mathrm{N}=66\end{array}$ & \\
\hline $\mathrm{TT}$ & 64 (98.46\%) & $64(96.97 \%)$ & \multirow[t]{3}{*}{0.5682} \\
\hline $\mathrm{CT}$ & $1(1.54 \%)$ & $2(3.03 \%)$ & \\
\hline \multirow[t]{3}{*}{$\mathrm{CC}$} & $0(0.00 \%)$ & $0(0.00 \%)$ & \\
\hline & \multicolumn{2}{|c|}{ Men $N=73$} & \\
\hline & $\begin{array}{l}\text { Infected } \\
\mathrm{N}=37\end{array}$ & $\begin{array}{l}\text { Uninfected } \\
\qquad \mathrm{N}=36\end{array}$ & \\
\hline $\mathrm{TT}$ & $37(100 \%)$ & $34(94.44 \%)$ & \multirow[t]{3}{*}{0.0894} \\
\hline $\mathrm{CT}$ & $0(0.00 \%)$ & $2(5.56 \%)$ & \\
\hline $\mathrm{CC}$ & $0(0.00 \%)$ & $0(0.00 \%)$ & \\
\hline
\end{tabular}

\section{Discussion}

Glycoprotein P, encoded by $A B C B 1$ is found on the surface of the digestive tract cellswhere it probably plays a protective function by eliminating xenobiotics from the cells to the extracellular environment $[3$, 4]. $A B C B 1$ gene is highly polymorphic. Since now over 50 SNPs of this gene has been described. It has been shown that several of these may be linked with the functioning of P-glycoprotein and are increasingly looking for a correlation between the occurrence of polymorphisms and predisposition to various diseases [3].

The distribution of specific genotypes occurrence frequency for the studied polymorphism obtained in this work was similar to that in the following populations: Polish, French, German, Italian, and Iranian [7, 8]. However, it was different than in Japanese population where the presence of the CC genotype was demonstrated [9].

The aim of this study was to assess the potential impact of polymorphism in position T-129C of $A B C B 1$ gene on the risk of peptic ulcer disease development. To the best of our knowledge this is the first $s$ research in peptic ulcer diseases of such kind. 
First of all, the comparison of genotypes frequencies between patients infected and uninfected with $\mathrm{H}$. pylori allows to assess the relationship of the tested SNP with the risk of $H$. pylori infection. However, there is no correlation between the studied polymorphism for the risk of infection with this bacterium, even in the division into subgroups by gender $(p=0.1743 ; p=0.5682 ; p=0.0894)$. According to our state of knowledge, this is the first such analysis, therefore it cannot be compared with other results.

The comparison of genotype frequencies between peptic ulcer patients and healthy individuals allowed to evaluate the impact of the investigated SNP T-129C on the development of peptic ulcer. CT genotype occurred more often in the healthy individuals than in peptic ulcer patients $(4,26 \%$ and $2.45 \%$, respectively) and this was not statistically significant $(p=0.3977)$. Therefore, this polymorphism is not associated with an increased risk of developing peptic ulcer disease. These results are similar to the research of Komoto et al. in which the CT genotype for T-129C SNP was not associated with a higher risk development of colorectal cancer and esophageal cancer [9]. Moreover, Hu et al. suggested that CT of SNP T-129C increased the risk of diffuse large B-cell lymphoma (DLBCL) [10]. On the other hand, results of this work are contrary to the results of research results obtained by Koyama et al, where it was shown that the CT genotype contributed to the reduced mRNA expression for $A B C B 1$ and the increased risk of developing colorectal adenocarcinoma [11]. Lower levels of mRNA are probably associated with the reduction of the protective function of P-gp and accumulation of xenobiotics in cells and a higher risk of cancer development.

Nonetheless, the studied SNP may show the protective role of gastric mucosa defending it against $H$. pylori infection and peptic ulcer diseases development. Tanabe et al. indicated that T-129C polymorphism T allele is associated with increased P-gp activity and thus faster removal of toxic xenobiotics and protection function of this protein [5].

\section{Conclusions}

In conclusion, $\mathrm{T}-129 \mathrm{C}$ polymorphism of $A B C B 1$ gene is not associated with the risk of $H$. pylori infection and with peptic ulcer diseases development. Future studies would benefit from including patients from diverse populations.

\section{Abbreviations}

DLBCL - diffuse large B-cell lymphoma

GC - gastric cancer

P-gp - P-glycoprotein

PPIs - protein pomp inhibitors

PUD - peptic ulcer disease 
SNP - single nucleotide polymorphism

\section{Declarations}

\section{Ethics approval and consent to participate:}

The research was approved by the Ethical Committee of the Medical University of Lodz (RNN/195/13/KE) and was in accordance with the principles of the Declaration of Helsinki. Written informed consent was obtained from the patients prior to their participation in the research.

\section{Consent for publication:}

Not applicable

\section{Availability of data and material:}

The datasets used and/or analysed during the current study are available from the corresponding author on reasonable request.

\section{Competing interests:}

The authors declare that they have no competing interests.

\section{Funding:}

This work was supported by statutory funds of the Department of Pharmaceutical Biochemistry and Molecular Diagnostics, Medical University of Lodz [number 503/3-015-02/503-31-001] and research task of the Medical University of Lodz [number 502-03/3-015-02/502-34-080].

\section{Authors' contributions:}

MZN: planned and carried out the research, prepared statistical analysis, interpreted results, prepare manuscript; AJ: carried out the research, prepare statistical analysis; JP: carried out the research, prepared manuscript; AL: interpreted the patients data and obtained results ; prepared the manuscript, AK: carried out the research; DSZ: carried out the research; prepare manuscript; MM: prepared and verified manuscript; EB: planned the research, interpreted results, prepared and verified manuscript. All authors read and approved the final manuscript.

\section{Acknowledgements:}

Not applicable.

\section{References}


1. Miftahussurur M, Yamaoka Y. Helicobacter pylori virulence genes and host genetic polymorphisms as risk factors for peptic ulcer disease. Expert Rev Gastroenterol Hepatol. 2015;9(12):1535-1547. doi:10.1586/17474124.2015.1095089.

2. Ma J, Wu D, Hu X, Li J, Cao M, Dong W. Associations between cytokine gene polymorphisms and susceptibility to Helicobacter pylori infection and Helicobacter pylori related gastric cancer, peptic ulcer disease: A meta-analysis. PLoS One. 2017;12(4):e0176463. doi:10.1371/journal.pone.0176463.

3. Fromm MF: Genetically determined differences in P-glycoprotein function: implications for disease risk. Toxicology. 2002;181-182:299-303.

4. Ishikawa $\mathrm{T}$, Hirano $\mathrm{H}$, Onishi Y, Sakurai $\mathrm{A}$, Tarui S: Functional evaluation of $A B C B 1$ (P-glycoprotein) polymorphisms: high-speed screening and structure-activity relationship analyses. Drug Metab Pharmacokinet. 2004;19(1):1-14.

5. Tanabe M, leiri I, Nagata N, Inoue K, Ito S, Kanamori Y, Takahashi M, Kurata Y, Kigawa J, Higuchi S, et al: Expression of P-glycoprotein in human placenta: relation to genetic polymorphism of the multidrug resistance (MDR)-1 gene. J Pharmacol Exp Ther. 2001;297(3):1137-43.

6. Salagacka-Kubiak A, Zebrowska M, Jelen A, Mirowski M, Balcerczak E: Assessment of TNFA polymorphisms at positions -857 and -863 in Polish peptic ulcer patients. Adv Med Sci. 2016;61(1):164-168. doi.org/10.1016/j.advms.2015.12.002.

7. Jeannesson E, Albertini L, Siest G, Gomes AM, Ribeiro V, Aslanidis C, Schmitz G, Visvikis-Siest S: Determination of $A B C B 1$ polymorphisms and haplotypes frequencies in a French population. Fundam Clin Pharmacol. 2007;21(4):411-8. doi:10.1111/j.1472-8206.2007.00507.x

8. Maleki M, Sayyah M, Kamgarpour F, Karimipoor M, Arab A, Rajabi A, Gharagozli K, Shamshiri AR, Shahsavand Ananloo E: Association between ABCB1 T-129C Polymorphism and Drug-Resistant Epilepsy in Iranian Female Patients. Iran Biomed J. 2010;14(3):89-96.

9. Komoto C, Nakamura T, Sakaeda T, Kroetz DL, Yamada T, Omatsu H, Koyama T, Okamura N, Miki I, Tamura T, et al.: MDR1 haplotype frequencies in Japanese and Caucasian, and in Japanese patients with colorectal cancer and esophageal cancer. Drug Metab Pharmacokinet. 2006;21(2):126-32.

10. Hu LL, Yu B, Yang J: MDR1 polymorphisms associated with risk and survival in diffuse large B-cell lymphoma. Leuk Lymphoma. 2013 ;54(6):1188-93. doi: 10.3109/10428194.2012.736980.

11. Koyama T, Nakamura T, Komoto C, Sakaeda T, Taniguchi M, Okamura N, Tamura T, Aoyama N, Kamigaki T, Kuroda Y, et al.: MDR1 T-129C polymorphism can be predictive of differentiation, and thereby prognosis of colorectal adenocarcinomas in Japanese. Biol Pharm Bull. 2006;29(7):1449-53. 